\title{
Zitierweise und Siglen
}

Kant wird nach der Ausgabe der Preußischen Akademie der Wissenschaften (Berlin 1902ff.) zitiert, der sogenannten „Akademie-Ausgabe“, z. B. VIII $289=$ Band VIII, Seite 289. Der Text wird dabei, wie heute gemeinhin üblich, in behutsam modernisierter Schreibweise wiedergegeben. Auf die Schrift Metaphysische Anfangsgründe der Tugendlehre (= Zweiter Teil der Metaphysik der Sitten) wird in der Regel ohne Angabe des Bandes nur mit der Seitenzahl verwiesen. Bei der Kritik der reinen Vernunft werden die Seitenzahlen der ersten $(=\mathrm{A})$ oder zweiten (= B) Auflage angegeben, z. B. KrV, B xvii = 2. Auflage, Seite xvii.

Auf andere Literatur wird mit dem Namen des Verfassers und dem Erscheinungsjahr Bezug genommen.

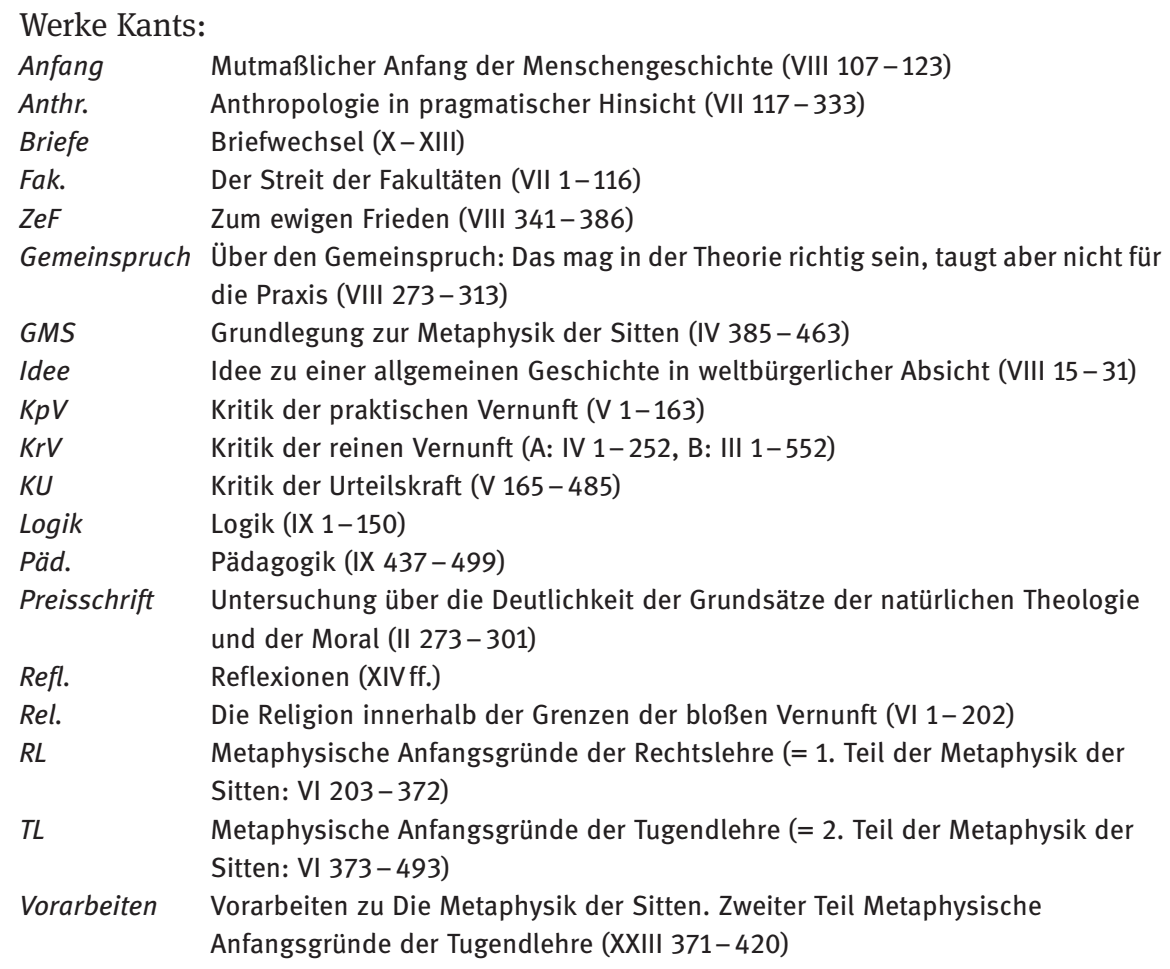


